\title{
Human Arylamine $N$-Acetyltransferase 1 Is Inhibited by the Dithiocarbamate Pesticide Thiram ${ }^{\text {ฐ }}$
}

\author{
Ximing Xu, Cécile Mathieu, ${ }^{1}$ Jérémy Berthelet, Romain Duval, ${ }^{2}$ Linh Chi Bui, Florent Busi, \\ Jean-Marie Dupret, and Fernando Rodrigues-Lima \\ Université Paris Diderot, Sorbonne Paris Cité, Unité BFA, CNRS UMR 8251, Paris, France (X.X., C.M., J.B., R.D., L.C.B., F.B., \\ J.-M.D., F.R.L.); and Institute of Bioinformatics and Medical Engineering, School of Electrical and Information Engineering, \\ Jiangsu University of Technology, Changzhou, China (X.X.)
}

Received March 1, 2017; accepted June 26, 2017

\section{ABSTRACT}

Thiram (tetramethylthiuram disulfide) is a representative dithiocarbamate (DTC) pesticide used in both the field and as a seed protectant. The widespread use of Thiram and other DTC pesticides has raised concerns for health, because these compounds can exert neuropathic, endocrine disruptive, and carcinogenic effects. These toxic effects are thought to rely, at least in part, on the reaction of Thiram (and certain of its metabolites) with cellular protein thiols with subsequent loss of protein function. So far, a limited number of molecular targets of Thiram have been reported, including few enzymes such as dopamine $\beta$-hydroxylase, $11 \beta$-hydroxysteroid dehydrogenase, and brain glycogen phosphorylase. We provide evidence that Thiram is an inhibitor $\left(K_{\mathrm{I}}=23 \mu \mathrm{M} ; k_{\text {inact }}=0.085 \mathrm{~second}^{-1} ; k_{\text {inact }} / K_{\mathrm{I}}=3691 \mathrm{M}^{-1} \cdot \mathrm{s}^{-1}\right)$ of human arylamine $N$-acetyltransferase 1 (NAT1), a phase II xenobiotic-metabolizing enzyme that plays a key role in the biotransformation of aromatic amine xenobiotics. Thiram was found to act as an irreversible inhibitor through the modification of NAT1 catalytic cysteine residue as also reported for other enzymes targeted by this pesticide. We also showed using purified NAT1 and human keratinocytes that Thiram impaired the $N$-acetylation of 3,4-dichloroaniline (3,4-DCA), a major toxic metabolite of aromatic amine pesticides (such as Diuron or Propanil). As coexposure to different classes of pesticides is common, our data suggest that pharmacokinetic drug-drug interactions between DTC pesticides such as Thiram and aromatic amine pesticides may occur through alteration of NAT1 enzymes functions.

\section{Introduction}

Thiocarbamates (including dithiocarbamates) are an important class of pesticides. Among this group of chemicals, Thiram (tetramethylthiuram disulfide) is a representative dithiocarbamate (DTC) pesticide widely used as a fungicide for treatment of crops, vegetables, seeds, and ornamental plants as well as a vulcanizing agent in rubber industry (Cereser et al., 2001; Rath et al., 2011; Mathieu et al., 2015). The widespread use of DTC pesticides has raised concerns for human health, in particular for agricultural workers (van Boxtel et al., 2010; Rath et al., 2011). In addition, the possibility of exposure to DTCs through contamination of

This work was supported by University Paris Diderot and CNRS. X.X. was supported by a PhD fellowship from the China Scholarship Council, C.M. was supported by a PhD fellowship from University Paris Diderot (Ecole Doctorale BioSPC), J.B. is supported by a $\mathrm{PhD}$ fellowship from Région Ile de France (DIM Cancéropole 2015), and R.D. was supported by a PhD fellowship from Région Ile de France (Allocation hors DIM 2012) and University Paris Diderot.

${ }^{1}$ Current affiliation: St Jude Children's Research Hospital, Department of Cell and Molecular Biology, Memphis, TN

${ }^{2}$ Current affiliation: Institute for Cancer Genetics and Herbert Irving Comprehensive Cancer Center, Columbia University, New York City, NY.

https://doi.org/10.1124/mol.117.108662.

S This article has supplemental material available at molpharm.aspetjournals. org. foodstuff has been put forward, because residues of DTC are found often in fruits, vegetables, and cereals (van Boxtel et al., 2010). Exposure to DTCs such as Thiram is associated with various toxic effects including renal failure as well as neuronal and developmental toxicity. Reproductive, endocrine disruptive, carcinogenic and teratogenic effects were also reported (Rath et al., 2011; Rasaputra et al., 2013). Exposure to DTCs occurs mainly from their absorption through skin and/or by ingestion and inhalation. In addition, the lipophilic properties of DTCs allow them to pass through cell membranes and physiologic barriers, including blood-brain and fetal-placental barriers (Frank et al., 1995; Rath et al., 2011). The toxic effects of DTCs are thought to rely, at least in part, on the formation of protein covalent adducts that perturb protein functions. In addition, DTC can also alter protein functions through chelation of metal ions (Rath et al., 2011; Viquez et al., 2012; Mathieu et al., 2015). Certain metabolites of DTCs (such as sulfoxide or sulfone forms) are also reactive. The toxic effects of DTC are thus thought to be due to the parent compounds and their metabolites (Jin et al., 1994; Staub et al., 1998; Mathieu et al., 2015, 2017). So far, Thiram pesticide has been clearly shown to impair the activity of few enzymes, i.e., dopamine $\beta$-hydroxylase, $11 \beta$-hydroxysteroid dehydrogenase,

ABBREVIATIONS: AcCoA, acetyl-coenzyme A; 3.4-DCA, 3.4-dichloroaniline; 3.5-DCA, 3.5-dichloroaniline; DETC, S-methyl- $N, N$-diethylthiocarbamate; DMAB, 4-dimethylaminobenzaldehyde; DTC, dithiocarbamate; DTT, dithiothreitol; HPCL, high-pressure liquid chromatography; 5-IAF, 5-iodoacetamidefluorescein; $\mathrm{k}_{\mathrm{obs}}$, apparent first-order inhibition rate constant; $k_{\text {inact }}$, maximum rate inhibition constant; $\mathrm{K}_{\mathrm{l}}$, concentration of inhibitor to achieve half-maximal rate of inhibition; NAT1, arylamine N-acetyltransferase 1; PABA, p-aminobenzoic acid; PNPA, p-nitrophenylacetate; XME, xenobiotic-metabolizing enzyme. 
lysyl oxidase, and brain glycogen phosphorylase (Lippmann and Lloyd, 1969; Caroldi and De Paris, 1995; Atanasov et al., 2003; Garbrecht et al., 2006; van Boxtel et al., 2010; Mathieu et al., 2017).

Arylamine $N$-acetyltransferases (NAT) are phase II xenobiotic-metabolizing enzymes (XME) that catalyze the transfer of an acetyl group from acetyl-coenzyme A (AcCoa) to the nitrogen or oxygen group of aromatic amine chemicals (Hein et al., 2000). As a consequence, these enzymes are key players in the detoxification and/or bioactivation of several aromatic amine drugs and carcinogens (Hein et al., 2000; Sim et al., 2012). In humans, there are two NAT isozymes (NAT1 and NAT2) that differ in substrate specificity and tissue distribution. NAT2 is found mainly in liver and gut, whereas NAT1 is ubiquitously expressed (Hein et al., 2000; Butcher and Minchin, 2012; Sim et al., 2012). In addition to xenobiotic metabolism, recent studies indicate that the NAT1 enzyme could be involved in other functions. For instance, NAT1 has been shown to act as a folate-dependent acetyl-coenzyme A hydrolase (Laurieri et al., 2014; Stepp et al., 2015). This NAT isozyme has also been reported to play a role in 5-methyltetrahydrofolate and $S$-adenosylmethionine metabolism (Witham et al., 2013). More recent data indicate that human NAT1 is involved in methionine salvage pathway (Witham et al., 2017). Among the very large panel of different aromatic amine chemicals (drugs, dyes, combustionderived carcinogens, etc.) that are metabolized by NAT enzymes, it is known that these XME contribute significantly to the metabolism of several aromatic amine pesticides (also known as aniline/anilide pesticides) such as diuron, linuron, chlorotoluron, or vinclozolin and their toxic by-products such as 3,4-dichloroaniline (3,4-DCA) or 3,5-dichloroaniline (3,5-DCA) (Tweedy et al., 1970; Tixier et al., 2002; Kim and Guengerich, 2005; Rodrigues-Lima et al., 2006; Martins et al., 2009). In addition to the genetic mechanisms that govern the expression and activity of NAT enzymes (mainly polymorphisms), nongenetic factors such as certain chemicals (reactive oxygen species, drugs, heavy metals) can also act as inhibitors of these enzymes (Dairou et al., 2005; Liu et al., 2008; RodriguesLima et al., 2008; Butcher and Minchin, 2012; Dierolf et al., 2012; Duval et al., 2016). Interestingly, it has been shown that certain pesticides, including organophosphates or DTCs, are able to alter xenobiotic metabolism pathways through inhibition of XME, in particular CYP P450 (Brady et al., 1991; Hernández et al., 2013).

Using molecular, cellular, and enzyme kinetics approaches, we report here that Thiram, a widely used DTC pesticide, is an irreversible inhibitor of human NAT1 enzyme $\left(K_{\mathrm{I}}=\right.$ $23 \mu \mathrm{M} ; k_{\text {inact }}=0.085$ second $\left.^{-1} ; k_{\text {inact }} / K_{\mathrm{I}}=3691 \mathrm{M}^{-1} \cdot \mathrm{s}^{-1}\right)$. We show that the $N$-acetylation of 3,4 -DCA (a major toxic metabolite of aromatic amine pesticides) by purified human NAT1 was readily inhibited by Thiram. Accordingly, we found that exposure of HaCat cells to Thiram led to the impairment of NAT1-dependent acetylation of 3,4-DCA. Taken together, our data indicate that Thiram may impair the NAT1-dependent acetylation of aromatic amines such as 3,4-DCA. Moreover, because concomitant exposure to different types of pesticides is common (in particular in agriculture), our result suggests that pharmacokinetic drug-drug interactions may exist between DTC and aromatic amine pesticides through inhibition of NAT1 enzyme (Hernández et al., 2013).

\section{Materials and Methods}

Materials. Thiocarbamate pesticides (triallate, thiobencarb, cycloate, vernolate, $S$-ethyl-dipropylthiocarbamate, molinate, ethiolate, pebulate, butylate), dithiocarbamate pesticides (ammonium pyrrolidinedithiocarbamate and Thiram), 3,4-dichloroaniline (3,4DCA), $p$-aminobenzoic acid (PABA), $p$-nitrophenylacetate (PNPA), and acetyl-coenzyme A (AcCoA) were from Sigma-Aldrich (Saint-QuentinFallavier, France). The sulfone form of $S$-methyl- $N, N$-diethylthiocarbamate was from Toronto Research Chemicals Inc. (Toronto, Canada). $N$-Acetyl3,4-DCA was purchased from Interchim (Montluçon, France). PD Minitrap G25 columns for buffer exchange were from GE Healthcare (Aulnay sous Bois, France). All other reagents were purchased from Sigma-Aldrich otherwise noted. The pesticides were dissolved in DMSO at $100 \mathrm{mM}$ concentration.

Expression and Purification of Recombinant Human NAT1. Human NAT1 enzyme was expressed and purified using BL21(DE3) Escherichia coli strain transformed with a pET28a plasmid containing the cDNA of human NAT1 as previously described (Dairou et al., 2004). The purified enzyme was reduced by $10 \mathrm{mM}$ DTT for 10 minutes in ice before dialysis against $25 \mathrm{mM}$ Tris- $\mathrm{HCl}, 150 \mathrm{mM} \mathrm{NaCl}, \mathrm{pH} 7.5$ (reaction buffer). The protein concentration was determined by the Bradford reagent (Bio-Rad, Marne la Coquette, France), and purity was assessed by SDS-PAGE and Coomassie staining. Purified recombinant human NAT1 was stored at $-80^{\circ} \mathrm{C}$ until use.

Assay of the Activity of Purified Recombinant NAT1 Using the PNPA Method. Human NAT1 activity was assayed using the PNPA method. This approach allows readily assaying the activity of purified NAT enzyme in 96-well plates. This continuous NAT assay is cheap, rapid, and has been used in several studies (Mushtaq et al., 2002; Wang et al., 2005; Malka et al., 2009; Laurieri et al., 2014). To this end, $80 \mu \mathrm{l}$ of mixture containing the NAT1 enzyme was mixed with $10 \mu \mathrm{l}$ of PABA ( $500 \mu \mathrm{M}$ for final concentration) in reaction buffer. The reaction was initiated by the addition of $10 \mu \mathrm{l}$ PNPA ( $2 \mathrm{mM}$ final concentration). The formation of the product $p$-nitrophenol was detected by measuring the absorbance at $405 \mathrm{~nm}$. Incubations were conducted at $37^{\circ} \mathrm{C}$ in a 96 -well plate and the reaction rate was determined by monitoring continuously the absorbance at $405 \mathrm{~nm}$ using a plate reader (BioTek, Colmar, France). Although the nonspecific hydrolysis of PNPA in absence of enzyme or PABA was found to be less than $1 \%$ of the hydrolysis of PNPA in presence of enzyme or PABA, the data were nonetheless corrected by subtracting the nonspecific hydrolysis of PNPA in the absence of enzyme.

Effect of Thiram on the $\boldsymbol{N}$-acetylation of 3,4-DCA by Purified Recombinant NAT1. The 4-dimethylaminobenzaldehyde (DMAB) method was used to assess the effect of Thiram on the acetylation of 3,4-dichloroaniline (3,4-DCA) by purified NAT1. This NAT assay allows to measure the rates of $N$-acetylation of arylamine substrates by NAT enzymes. This approach is rapid, cheap, and can be used in 96-well plates with either purified NAT enzymes or with cell extracts. This assay has been used in several studies, where it replaced more tedious HPLC approaches (Sinclair et al., 1998; Kawamura et al., 2008; Russel et al., 2009; Laurieri et al., 2014). To this end, NAT1 (2.5 $\mu \mathrm{M}$ final concentration) was first incubated with Thiram (40 $\mu \mathrm{M}$ final concentration) for 30 minutes at $37^{\circ} \mathrm{C}$ in a total volume of $50 \mu \mathrm{l}$. The mixture was then diluted (40 times) with reaction buffer ( $25 \mathrm{mM}$ Tris- $\mathrm{HCl}, \mathrm{pH}$ 7.5). Aliquots $(3 \mu \mathrm{l})$ were removed and assayed in a total volume of $50 \mu \mathrm{l}$ containing 3,4-DCA (500 $\mu \mathrm{M}$ final concentration) and AcCoA (500 $\mu \mathrm{M}$ final concentration) for 30 minutes at $37^{\circ} \mathrm{C}$. The reaction was quenched by adding $40 \mu \mathrm{l}$ of cold trichloroacetic acid ( $40 \% \mathrm{vol} / \mathrm{vol}$ in water). Finally, $100 \mu \mathrm{l}$ of DMAB (5\% w/v, in 9:1 acetonitrile and water) were added to the mixture, and absorbance at $450 \mathrm{~nm}$ was measured in a 96-well plate reader. The amount of residual (nonacetylated) 3,4-DCA was determined from a standard curve of 3,4-DCA.

Effects of Pesticides on Human NAT1. Pesticides $(0-100 \mu \mathrm{M}$ final concentration) were independently mixed with human NAT1 (2.5 $\mu \mathrm{M}$ final concentration) in reaction buffer $(25 \mathrm{mM}$ Tris- $\mathrm{HCl}$, $150 \mathrm{mM} \mathrm{NaCl}, \mathrm{pH}$ 7.5). Total volume of the reaction was $50 \mu \mathrm{l}$. Upon 
incubation for 30 minutes at $37^{\circ} \mathrm{C}$, aliquots $(5 \mu \mathrm{l})$ were diluted (40 times) with reaction buffer and $80 \mu \mathrm{l}$ was taken for measurement of the residual human NAT1 activity using the PNPA assay as described above. Enzyme activity was expressed as the percentage of the control (no pesticide). In all assays, the final concentration of enzyme was $50 \mathrm{nM}$. Controls were carried out in presence of DMSO.

To determine whether reducing agents could reactivate Thiraminhibited human NAT1, the enzyme $(2.5 \mu \mathrm{M}$ final) was first preincubated with Thiram $\left(40 \mu \mathrm{M}\right.$ final concentration, 30 minutes at $\left.37^{\circ} \mathrm{C}\right)$ and further incubated with dithiothreitol (DTT, 1-10 $\mathrm{mM}$ final concentration) for 10 minutes at $37^{\circ} \mathrm{C}$ in a total volume of $50 \mu \mathrm{l}$. Aliquots $(5 \mu \mathrm{l})$ were diluted (40 times) with reaction buffer, and $80 \mu \mathrm{l}$ was taken for measurement of the residual human NAT1 activity using the PNPA assay as described above. Controls were carried out without Thiram, without DTT, and with DTT only.

To investigate whether reducing agents could protect human NAT1 from the inhibitory effect of Thiram, the enzyme was incubated with Thiram (40 $\mu \mathrm{M}$ final concentration) in the presence or absence of different concentrations of DTT (1-10 $\mathrm{mM}$ final concentration) for 30 minutes at $37^{\circ} \mathrm{C}$ in a total volume of $50 \mu \mathrm{l}$. Aliquots $(5 \mu \mathrm{l})$ were diluted (40 times) with reaction buffer and $80 \mu \mathrm{l}$ were taken for measurement of the residual human NAT1 activity using the PNPA assay as described above. Controls were carried out without Thiram, without DTT, and with DTT only.

To test the ability of the NAT1 enzyme cofactor AcCoA to protect the enzyme from the inhibitory effect of Thiram, NAT1 was incubated with Thiram ( $40 \mu \mathrm{M}$ final concentration) in the presence or absence of $\mathrm{AcCoA}$ ( $1 \mathrm{mM}$ final concentration) for 30 minutes at $37^{\circ} \mathrm{C}$ in a total volume of $50 \mu \mathrm{l}$. Aliquots $(5 \mu \mathrm{l})$ were diluted (40 times) with reaction buffer and $80 \mu \mathrm{l}$ were taken for measurement of the residual human NAT1 activity using the PNPA assay as described above. Controls were carried out without Thiram, with AcCoA only, and without AcCoA.

To determine whether the inhibition of human NAT1 by Thiram is irreversible, NAT1 (2.5 $\mu \mathrm{M}$ final concentration) was incubated with or without Thiram ( $40 \mu \mathrm{M}$ final concentration) for 30 minutes at $37^{\circ} \mathrm{C}$ in a total volume of $100 \mu \mathrm{l}$. Aliquots $(25 \mu \mathrm{l})$ were diluted (40 times) with reaction buffer to a total volume of $1 \mathrm{ml}$. Eighty microliters was taken for measurement of the residual human NAT1 activity using the PNPA assay as described above. In parallel, $500 \mu \mathrm{l}$ were buffer exchanged using a PD Minitrap G25 column (equilibrated with reaction buffer). Eighty microliters of buffer-exchanged samples was assayed for residual human NAT1 activity using the PNPA assay as described above.

Labeling of Cysteine Residues of Human NAT1 with Fluorescein-Conjugated Iodoacetamide. The modification of NAT1 cysteine residues by Thiram was monitored using 5-iodoacetamidefluorescein (5-IAF) labeling, as previously described (Duval et al., 2016). Briefly, human NAT1 (2.5 $\mu \mathrm{M}$ final concentration) was incubated with or without Thiram $\left(0-25 \mu \mathrm{M}\right.$ final concentration) for 30 minutes at $37^{\circ} \mathrm{C}$, in $25 \mathrm{mM}$ Tris-HCl, $150 \mathrm{mM} \mathrm{NaCl}, \mathrm{pH}$ 7.5. Then 5-IAF $(100 \mu \mathrm{M}$, final concentration) was added and the mixture incubated for 10 minutes at $37^{\circ} \mathrm{C}$ in the dark. Samples were then subjected to SDS-PAGE and transferred on nitrocellulose membrane. 5-IAF labeling was detected by fluorescence measurements ( $\lambda_{\text {exc }}: 492 \mathrm{~nm} ; \lambda_{\text {em }}: 520 \mathrm{~nm}$ ). The membrane was also probed for recombinant NAT1 protein by immunodetection using a monoclonal anti-6X Histidine-tag antibody (Sigma-Aldrich).

Kinetic Analysis of Inhibition of NAT1 by Thiram. For the kinetic analysis of Thiram-dependent NAT1 inactivation, NAT1 $(1 \mu \mathrm{M}$ final concentration) was incubated with Thiram (final concentration of $2.5-10 \mathrm{mM}$ ) at $37^{\circ} \mathrm{C}$ in reaction buffer (total volume $50 \mu \mathrm{l}$ ). At various time intervals ( 30 seconds), aliquots $(5 \mu \mathrm{l})$ were removed and diluted 40 times with reaction buffer. Eighty microliters of each sample was assayed for residual human NAT1 activity using the PNPA assay as described above. The kinetic data were analyzed as reported in CornishBowden (2001) and Copeland (2005) for irreversible inhibitors using OriginPro 8.1 program (RITME Informatique, Paris, France). The apparent first-order inhibition rate constant $\left(k_{\text {obs }}\right)$ for each Thiram concentration was calculated from the linear regression of the natural logarithm of the percentage residual activity versus time:

$$
\left[\operatorname{Ln}(\% \text { residual activity })=k_{\text {obs }} \times t, \text { where } t \text { is time }\right](1) .
$$

The $k_{\text {obs }}$ values were plotted as a function of Thiram concentration, and the data were fitted to the following equation:

$$
k_{\text {obs }}=\left(k_{\text {inact }} \times \mathrm{I}\right) /\left(k_{\mathrm{I}}+\mathrm{I}\right)(2),
$$

where $k_{\text {obs }}$ is the apparent first-order inhibition rate constant, $k_{\text {inact }}$ is the first-order maximum rate inhibition constant, I is the concentration of inhibitor (Thiram), and $K_{\mathrm{I}}$ the concentration of inhibitor that achieves half-maximal rate of inhibition. The effectiveness of the inhibition can thus be quantified using the second-order rate constant $k_{\text {inact }} / K_{\mathrm{I}}$ (Copeland, 2005).

Effects of Thiram on the Acetylation of 3,4-DCA by Cultured HaCat Cells. Acetylation of 3,4-DCA in cultured HaCat cells was monitored by high-pressure liquid chromatography (HPLC). This approach allows for the monitoring qualitatively and quantitatively of both 3,4-DCA and $N$-acetylated 3,4-DCA in complex media such as the culture medium of cells. This method has been used widely used to assess the acetylation activity of NAT enzymes, including NAT1, in cellular contexts (Butcher et al., 2000; Butcher et al., 2004; Martins et al., 2009; Doll et al., 2010).

HaCat keratinocyte cells (a gift of Pr. B. Friguet, CNRS Université Paris 6 UMR 8256) were grown in six-well plates at $37^{\circ} \mathrm{C}$ under $5 \%$ $\mathrm{CO}_{2}$, in Dulbecco's modified Eagle's medium supplemented with $10 \%$ $(\mathrm{v} / \mathrm{v})$ fetal bovine serum. Cells were seeded at a density of 1000 cells/ well in triplicate and grown for 24 hours. Before treatment, HaCat cells were washed with phosphate-buffered saline and then exposed to Thiram or DETC-sulfone $(0-50 \mu \mathrm{M})$ for 1 hour at $37^{\circ} \mathrm{C}$. 3,4-DCA (500 $\mu \mathrm{M}$ final) was then added to the culture medium. Aliquots of culture medium were taken every hour (for up to 3 hours) for HPLC analysis of 3,4-DCA and $N$-acetylated 3,4-DCA. To this end, $20 \mu \mathrm{l}$ of medium was mixed with $20 \mu \mathrm{l}$ perchloric acid (15\% in water). After centrifugation (10 minutes at 10,000 g), $20 \mu \mathrm{l}$ of supernatant was injected into a Kromasil Eternity C18 reverse-phase HPLC column (Sigma Aldrich) (Martins et al., 2009). 3,4-DCA and $N$-acetylated 3,4DCA were used as standards, and results were normalized using the protein concentration of whole cell lysates.

Statistical Analysis. Analysis of variance or Student's $t$ test was calculated by Prism 5.03 (GraphPad Software, La Jolla, CA). Analysis of variance was followed by Dunnett's multiple-comparison test.

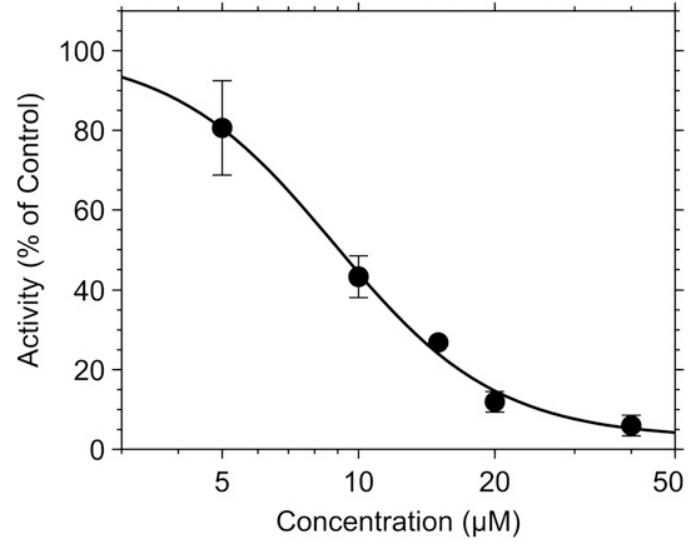

Fig. 1. Dose-dependent inhibition of human NAT1 by Thiram. Human NAT1 was incubated with increasing concentrations of Thiram (0-40 $\mu M$ final concentration) for 30 minutes at $37^{\circ} \mathrm{C}$ before activity measurement using the PNPA assay. Data represent mean values \pm S.D. of triplicate experiments. 
A

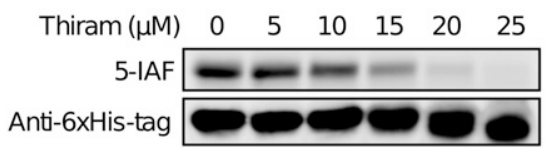

B
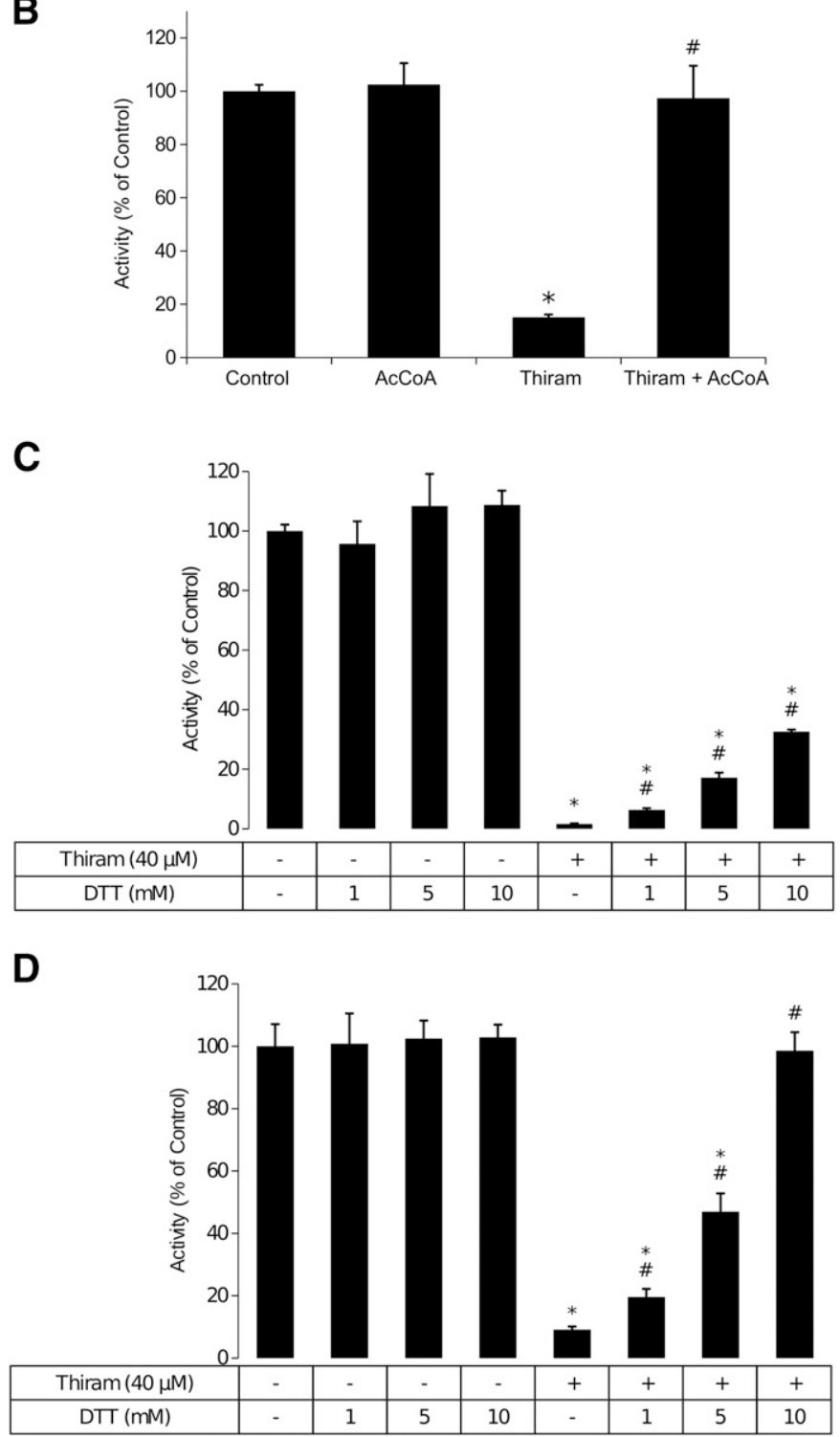

Fig. 2. Effects of the reducing agent DTT and the cofactor AcCoA on the Thiram-dependent inhibition of NAT1. (A) 5-IAF labeling of free cysteines in human NAT1 treated with Thiram. Thiram-treated NAT1 (40 $\mu \mathrm{M}$ final) was further incubated with 5-IAF $(100 \mu \mathrm{M}$ final concentration) for 10 minutes at $37^{\circ} \mathrm{C}$. Samples were run on SDS-PAGE, transferred to nitrocellulose membranes, and 5-IAF detected by measuring the fluorescence $(\lambda$ exc: $492 \mathrm{~nm} ; \lambda$ em: $520 \mathrm{~nm}$ ). NAT1 protein was revealed by immunodetection using an anti-6xHis-tag antibody. (B) Protective effects of the NAT1 cofactor AcCoA against Thiram-dependent inhibition of human NAT1. Human NAT1 was incubated with Thiram $(40 \mu \mathrm{M}$ final) in presence of $\mathrm{AcCoA}(1 \mathrm{mM})$ for 30 minutes at $37^{\circ} \mathrm{C}$ and assayed for NAT1 activity using the PNPA assay. ${ }^{*} P<0.05$ compared with the control; ${ }^{\#} P<$ 0.05 compared with the Thiram-treated enzyme. Data represent mean values \pm S.D. of triplicate experiments. (C) Reactivation of human NAT1 by the reducing agent DTT. Thiram-inhibited NAT1 $(40 \mu \mathrm{M})$ was further incubated with DTT for 15 minutes before activity assay using the PNPA assay. ${ }^{*} P<0.05$ compared with the controls (no Thiram); ${ }^{\#} P<0.05$ compared with the Thiram-treated enzyme (no DTT). Data represent mean values \pm S.D. of triplicate experiments. (D) Protective effects of the reducing agent DTT against Thiram-dependent inhibition of human NAT1. Human NAT1 was incubated with Thiram $(40 \mu \mathrm{M}$ final) in the

\section{Results}

The Dithiocarbamate Pesticide Thiram Inhibits Human NAT1. As stated above, thiocarbamate pesticides have been shown to react with thiol groups in proteins (Rath et al., 2011; Viquez et al., 2012; Mathieu et al., 2015). In addition, the structural similarity of the thioester group of the NAT cofactor AcCoA with thiocarbamates suggested that these chemicals could react with the catalytic cysteine of human NAT1 in a manner similar to that of AcCoA (Supplemental Fig. 1). In addition, disulfiram, a clinically used DTC has been shown to inhibit the activity of NAT1 (Malka et al., 2009). To determine whether thiocarbamate pesticides could impair the acetylation of aromatic amine xenobiotics by NAT1, we first investigated the impact of 11 different thiocarbamate pesticides (including two dithiocarbamates ammonium pyrrolidinedithiocarbamate and Thiram) on human NAT1 activity (Supplemental Fig. 1). Among the different compounds tested (data not shown), Thiram was the most effective at yielding almost full inhibition of NAT1 at $20 \mu \mathrm{M}$ concentration $(60 \pm 6 \%$ S.D. and $90 \pm 9 \%$ S.D. inhibition obtained with 10 and $20 \mu \mathrm{M}$ Thiram, respectively). As shown in Fig. 1, further analyses with Thiram confirmed that NAT1 was inhibited in a dose-dependent manner by this DTC pesticide with an $\mathrm{IC}_{50}$ value of $9 \pm 0.5$ S.D. $\mu \mathrm{M}$.

Human NAT1 is Irreversibly Inhibited by Thiram through the Modification of Its Catalytic Cysteine. To determine whether NAT1 cysteine residues are modified upon exposure to Thiram, we performed chemical-labeling experiments using 5-iodoacetamide-fluorescein (5-IAF), an alkylating agent that covalently and specifically labels free thiol groups. As shown in Fig. 2A, the incubation of human NAT1 with increasing concentrations of Thiram led to a dosedependent modification of NAT1 cysteine residues by Thiram, which is evidenced by the dose-dependent loss of the fluorescence signal. In addition, the modification of NAT1 cysteine residues by Thiram correlated well with the dose-dependent inhibition of the enzyme (Fig. 1). To investigate whether the loss of NAT1 activity was due to the modification of the catalytic cysteine residue present in the active site of human NAT1, we performed substrate protection experiments using AcCoA. This natural cofactor of NAT enzyme is known to acetylate specifically the catalytic cysteine of NAT1, thus protecting it from reaction with chemicals as described by Liu et al. (2008). As shown in Fig. 2B, AcCoA fully protected the enzyme from inhibition by Thiram, thus indicating that inhibition of NAT1 activity by Thiram occurred through the modification of the catalytic cysteine.

Thiram has been shown to inhibit irreversibly the activity of $11 \beta$-hydroxysteroid dehydrogenase 2 through a modification of an active site cysteine that could not be reversed by the reducing agent DTT (Atanasov et al., 2003; Garbrecht et al., 2006). Therefore, to further investigate the molecular mechanism of the inhibition of human NAT1 by Thiram, we determined the ability of the reducing agent DTT to reactivate

presence of different concentrations of DTT $(1,5,10 \mathrm{mM})$ for 30 minutes at $37^{\circ} \mathrm{C}$, and then assayed for NAT1 activity using the PNPA assay. $* P<0.05$ compared with the controls (no Thiram); ${ }^{\#} P<0.05$ compared with the Thiram-treated enzyme (no DTT). Data represent mean values \pm S.D. of triplicate experiments. 
the Thiram-inhibited enzyme. As shown in Fig. 2C, DTT was found to poorly reactivate the inhibited enzyme with only $30 \%$ of the activity restored at high concentration of DTT (10 mM). As observed with $11 \beta$-hydroxysteroid dehydrogenase 2 (Atanasov et al., 2003), these results suggested that the irreversible inhibition of NAT1 was due to the formation of a stable adduct on the catalytic cysteine.

We also investigated the ability of DTT to prevent NAT1 from the inhibition by Thiram by coincubating the enzyme with Thiram and DTT. As shown in Fig. 2D, DTT was able to afford full protection against Thiram-dependent inhibition only at high concentration $(10 \mathrm{mM})$. At 1 and $5 \mathrm{mM}$ concentrations of DTT, the protection was partial (with $\sim 50 \%$ inhibition observed despite the presence of $5 \mathrm{mM}$ DTT). These data suggest that Thiram reacts more rapidly with the catalytic cysteine of NAT1 than with the thiol group of DTT, which is in agreement with the reactive nature of the catalytic cysteine residue of NAT1 (Rodrigues-Lima et al., 2001; Liu et al., 2008; Malka et al., 2009; Sim et al., 2012).

Finally, to confirm that Thiram acts as an irreversible inhibitor of human NAT1, Thiram-inhibited NAT1 was buffer-exchanged and assayed for NAT1 activity. As shown in Fig. 3, buffer-exchange did not yield recovery of the activity of NAT1 enzyme previously exposed to Thiram. This experiment supports that NAT1 inhibition by Thiram occurs through an irreversible mechanism, which is agreement with the data obtained above (Fig. 2).

Kinetic Analysis and Determination of the Second-Order Rate Constant of NAT1 Inhibition by Thiram. We then performed kinetic analysis to further characterize the inhibition of human NAT1 by Thiram. To this end, we carried out time course inhibition of the NAT1 enzyme at different Thiram concentrations (Fig. 4A). The enzyme was found to be inhibited in a time and dose-dependent manner by Thiram as shown in the plot of $k_{\text {obs }}$ values (apparent first-order inhibition rate constants for each Thiram concentration) as function of Thiram concentration (Fig. 4B). The data fitted well to
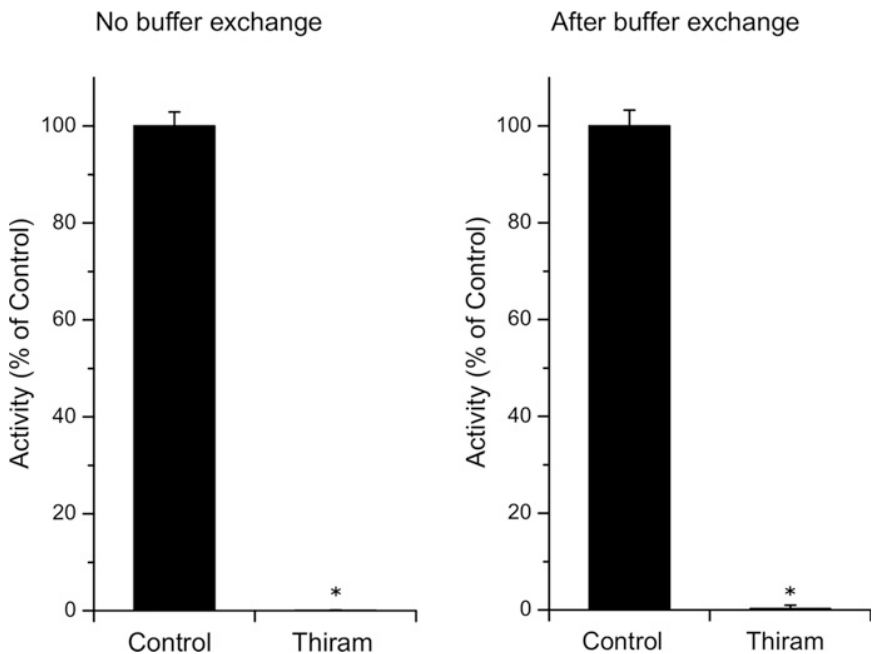

Fig. 3. Effect of buffer-exchange on the inhibition of NAT1 enzyme by Thiram. NAT1 enzyme $(2.5 \mu \mathrm{M})$ was first incubated for 30 minutes at $37^{\circ} \mathrm{C}$ with or without Thiram $(40 \mu \mathrm{M})$. The samples were assayed for NAT1 activity using the PNPA assay before (left panel) and after buffer exchange with PD Minitrap G25 columns (right panel). ${ }^{*} P<0.05$ compared control (no Thiram). Data represent mean values \pm S.D. of triplicate experiments. Statistical analysis was done by Student's $t$ test. the two-steps mechanism of irreversible inhibition equation $\left(k_{o b s}=\left(k_{\text {inact }} \times \mathrm{I}\right) /\left(K_{\mathrm{I}}+\mathrm{I}\right)\right.$, indicating that the inhibition by Thiram occurred through a two-step mechanism of inhibition that involves reversible binding of the inhibitor to enzyme followed by an irreversible step (Copeland, 2005). The $K_{\mathrm{I}}$ was found to be equal to $23 \mu \mathrm{M}$ and the $k_{\text {inact }}$ to be equal to 0.085 second $^{-1}$, which give a second-order rate constant of $k_{\text {inact }} / K_{\mathrm{I}}=3691 \mathrm{M}^{-1} \cdot \mathrm{s}^{-1}$. This rate of inhibition is higher than the rate of inhibition of NAT1 by acrolein, an aldehyde chemical, found to irreversibly inhibit the enzyme through a similar two-step mechanism $\left(k_{\text {inact }} / K_{\mathrm{I}}=57 \mathrm{M}^{-1} \cdot \mathrm{s}^{-1}\right.$ ) (Bui et al., 2013).

Thiram Impairs 3,4-DCA Acetylation by Purified Human NAT1 and in Cultured HaCat Cells. 3,4-DCA is a major toxic metabolite of aromatic amine pesticides known to
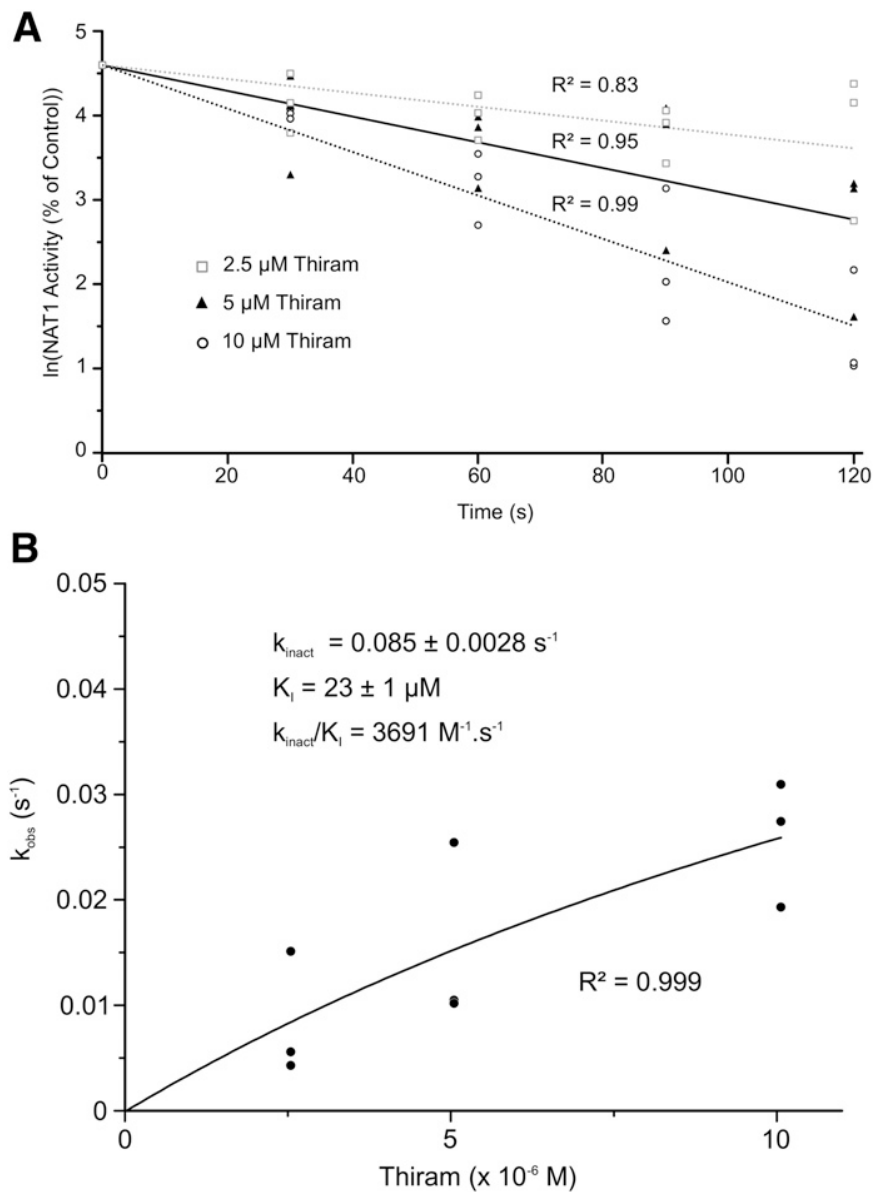

Fig. 4. Kinetics analysis of human NAT1 inhibition by Thiram. (A) Timeand concentration-dependent inhibition of NAT1. NAT1 $(1 \mu \mathrm{M})$ was incubated with different concentrations of Thiram $(0,2.5,5$, and $10 \mu \mathrm{M})$ at $37^{\circ} \mathrm{C}$. Aliquots were taken every 30 seconds and diluted 40 times with reaction buffer. Then, the residual NAT1 activity was measured using the PNPA assay. The data were analyzed as reported in Cornish-Bowden (2001) and Copeland (2005) for irreversible inhibitors using OriginPro 8.1 program. Briefly, the apparent first-order inhibition rate constant $\left(k_{\text {obs }}\right)$ for each Thiram concentration was obtained by linear regression from plots of the natural logarithm of the percentage residual activity versus time (eq. 1, see Materials and Methods). (B) Determination of inhibition constants $K_{\mathrm{I}}$ and $k_{\text {inact }}$. To obtain the first-order maximum rate inhibition constant $\left(k_{\text {inact }}\right)$ and $K_{\mathrm{I}}$ (the concentration of Thiram that achieves half-maximal rate of inhibition), the data were fitted to $k_{\text {obs }}=\left(k_{\text {inact }} \times \mathrm{I}\right) /\left(K_{\mathrm{I}}+\mathrm{I}\right)($ eq. 2 , see Materials and Methods). The second-order rate inhibition constant is equal to $k_{\text {inact }} / K_{\mathrm{I}}$. The $R$-squared value of the fit is performed with the mean of three independent experiment for each concentration. 
be biotransformed by NAT enzymes (Tixier et al., 2002; Martins et al., 2009; Yuan et al., 2017). We analyzed the impact of Thiram on the biotransformation of this pesticide by human NAT1. As shown in Fig. 5A, incubation of purified NAT1 with Thiram led to the inhibition of the $N$-acetylation of 3,4-DCA. Because skin is a major route of exposure to Thiram and aromatic amine pesticides, cellular experiments using the well-known human keratinocyte cell line HaCat were carried out. HaCat cells are known to express NAT1 enzyme and to display a functional NAT1dependent aromatic amine acetylation pathway (Bonifas et al., 2010; Scheitza et al., 2012). HaCat cells were exposed to Thiram and 3,4-DCA, and the $N$-acetylation of 3,4-DCA by endogenous NAT1 was followed using HPLC methods (Rodrigues-Lima et al., 2006; Martins et al., 2009). As shown in Fig. 5B, exposure to

A

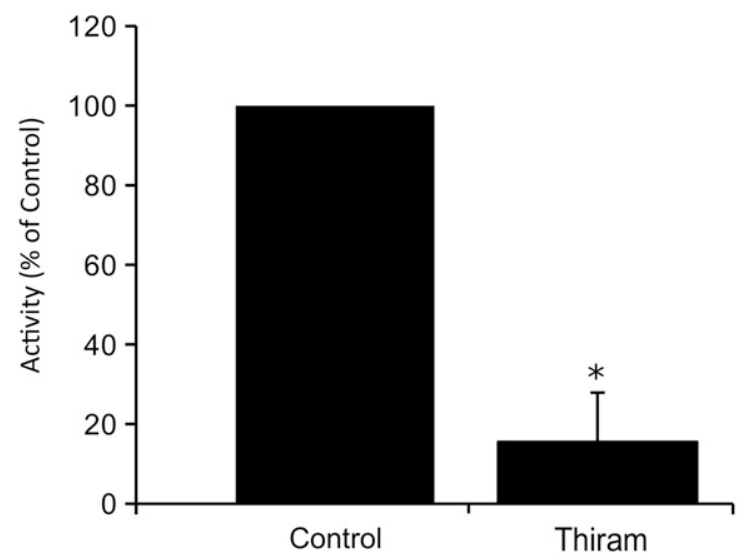

B

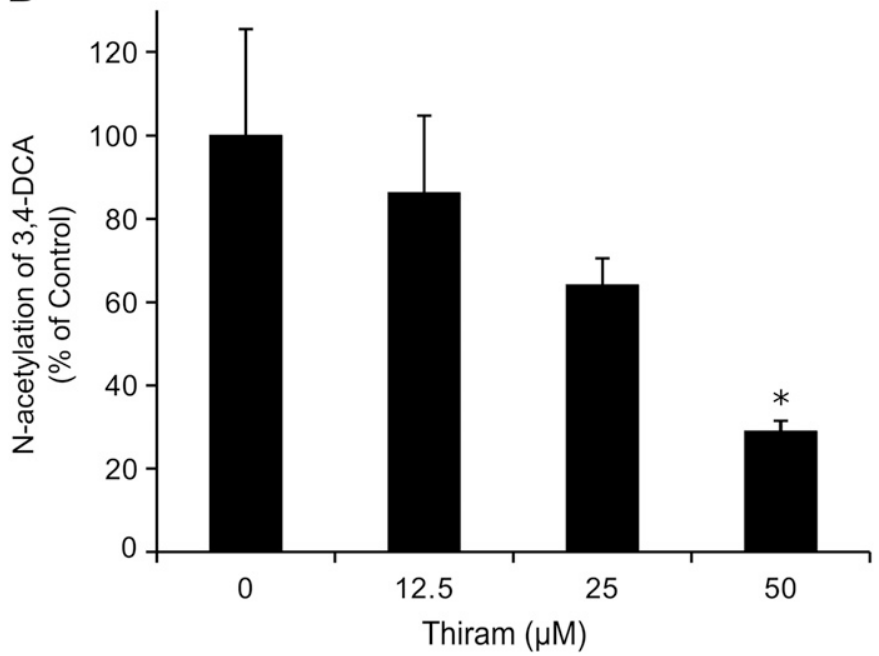

Fig. 5. Thiram inhibits 3,4-DCA $N$-acetylation by recombinant human NAT1 and in HaCat cells. (A) Inhibition of 3,4-DCA acetylation by purified human NAT1. The enzyme was incubated with Thiram (40 $\mu \mathrm{M}$ final) for 30 minutes at $37^{\circ} \mathrm{C}$ before incubation with 3,4-DCA and AcCoA for 30 minutes at $37^{\circ} \mathrm{C}$. NAT1 activity toward 3,4-DCA was then measured using the DMAB method as described in Materials and Methods. $* P<0.05$ compared with control. Data represent mean values \pm S.D. of triplicate experiments. Statistics analysis was done by Student's $t$ test. (B) Thiram inhibits the endogenous $N$-acetylation of 3,4-DCA in cultured HaCat cells. HaCat cells were exposed or not to different concentrations of Thiram (0$50 \mu \mathrm{M}$ ) for 1 hour at $37^{\circ} \mathrm{C}$ in $\mathrm{PBS} \mathrm{Ca}{ }^{2+} / \mathrm{Mg}^{2+}$. Cells were then cultured in Dulbecco's modified Eagle's medium containing $500 \mu \mathrm{M} 3$ 3,4-DCA for 3 hours. Every hour, aliquots of the cell culture medium were taken and the amount of $N$-acetylated 3,4-DCA measured by HPLC. ${ }^{*} P<0.05$ compared with the control. Data represent mean values \pm S.D. of triplicate experiments.
Thiram impaired the $N$-acetylation of 3,4-DCA mediated by NAT1 in a dose-dependent manner.

Thiocarbamates including Thiram can be biotransformed into different reactive metabolites that can also react with cysteine residues. In particular, thiocarbamates can undergo oxidation, forming successively a sulfoxide and a final sulfone metabolite that can react with thiol groups in proteins (Lipsky et al., 2001; Viquez et al., 2012; Mathieu et al., 2015). Because the sulfone metabolite of Thiram, DMTC-sulfone, is not commercially available, we investigated the impact of DETC-sulfone on recombinant NAT1. This compound differs only from DMTC-sulfone by a methyl group. In addition, disulfiram, the dithiocarbamate that is the parent compound of DETC-sulfone, is also an irreversible inhibitor of NAT1 (Malka et al., 2009). As observed with Thiram, we found that exposure to DETC-sulfone led to a dose-dependent inhibition of recombinant human NAT1 (with an $\mathrm{IC}_{50}$ of $1.7 \pm 0.1 \mu \mathrm{M}$ ) (Supplemental Fig. 2A). This inhibition was concomitant with a loss of 5-IAF fluorescence signal, suggesting that the inhibition was also associated with the modification of cysteine residues of the enzyme as shown for Thiram (Supplemental Fig. 2B). Thus, altogether, these data supported that NAT1 is a target of Thiram pesticide but also of its sulfone metabolite.

\section{Discussion}

Thiocarbamates (including dithiocarbamates) are organosulfur compounds extensively used as pesticides. Exposure to these compounds is associated with different toxic effects (Rath et al., 2011; Mathieu et al., 2015). However, very little is known about the possible metabolic interactions between thio/dithiocarbamates and other class of xenobiotics including pesticides (Boobis et al., 2008; Hernández et al., 2013). Here we report that the xenobiotic-metabolizing enzyme NAT1 is inhibited by Thiram, a prototypic thiocarbamate widely used as pesticide. We provide mechanistic and kinetic evidence that the inhibition of NAT1 by Thiram occurs through the irreversible modification of the reactive catalytic cysteine of the enzyme based on a classic two-step mechanism (Copeland, 2005). The toxic effects of Thiram are thought to rely, at least in part, on its reaction with cysteine residues in target proteins that drive their loss of function (Rath et al., 2011). Our results are in agreement with studies carried out on $11 \beta$ hydroxysteroid dehydrogenase showing that Thiram reacts with cysteine residue in the active site leading to its irreversible inhibition (Atanasov et al., 2003). Similarly, we found that Thiram-inhibited NAT1 was only slightly reactivated by high concentrations of the reducing agent such as DTT, indicating that the disulfide adduct formed upon reaction of the catalytic cysteine with Thiram is stable and not readily reducible by DTT as also observed with $11 \beta$-hydroxysteroid dehydrogenase (Atanasov et al., 2003). We also found that oxidative metabolites of Thiram such as its sulfone metabolite may also impair the activity of NAT1. Interestingly, sulfone metabolites of thiocarbamate chemicals (such as DETC-sulfone the metabolite of disulfiram) have been shown to react with cysteine residues and also to impair enzyme activity through covalent reaction with cysteines ( $\mathrm{Hu}$ et al., 1997; Zimmerman et al., 2004).

So far, a limited number of enzymes have been reported to be inhibited by Thiram (Lippmann and Lloyd, 1969; Caroldi 
and De Paris, 1995; Atanasov et al., 2003; Garbrecht et al., 2006; van Boxtel et al., 2010; Mathieu et al., 2017). In addition to these enzymes, our data show that Thiram is also able to inhibit a phase II xenobiotic-metabolizing enzyme known to play a major role in the metabolism of arylamine xenobiotics. Although other DTCs had been shown to alter the activity of certain cytochromes P450 or GST, so far no study had addressed the effect of Thiram on a XME (Rath et al., 2011; Mathieu et al., 2015). NAT enzymes are known to acetylate a large variety of aromatic amines xenobiotics, including drugs, carcinogens, pesticides, and their toxic metabolites such as 3,4-DCA and thus to impact their pharmacological and/or toxicological outcome (Kim and Guengerich, 2005; Martins et al., 2009; Sim et al., 2012). We found that Thiram was able to impair the NATdependent acetylation of 3,4-DCA, a well-known toxic metabolite of several aromatic amine pesticides (Tixier et al., 2002; Martins et al., 2009; Yuan et al., 2017). In addition, we also showed that exposure of cultured human keratinocyte cells to Thiram led to the impairment of the $N$-acetylation of 3,4-DCA by NAT1. Altogether these data point to potential pharmacokinetic drug-drug interactions between Thiram and aromatic amine xenobiotics metabolized by NAT1. In particular, as pesticides occur frequently as mixtures, our results suggest possible metabolic interactions between DTCs such as Thiram and aniline pesticides (such as linuron or propanil) through alteration of NAT enzyme functions. Pharmacokinetic drug-drug interactions between different classes of pesticides have been reported (Hernández et al., 2013). These are often the result of one pesticide altering the absorption, distribution, metabolism, or elimination of the others. For instance, it has been shown that certain organophosphate pesticides decrease the organism's ability to detoxify pyrethroid pesticides due to esterase inhibition (Hernández et al., 2013).

To conclude, using a combination of molecular, kinetic, and cellular studies, we provide evidence that Thiram, a widely used dithiocarbamate pesticide, impairs the NAT1-dependent acetylation of xenobiotics, including toxic aromatic pesticide metabolites. More broadly, our data suggest that pharmacokinetic drug-drug interactions between certain DTC pesticides and aromatic amine pesticides may occur through the inhibition of NAT1 enzyme.

\section{Acknowledgments}

The authors thank the technical platform "BioProfiler-UFLC" for provision of HPLC facilities.

\section{Authorship Contributions}

Participated in research design: $\mathrm{Xu}$, Mathieu, Rodrigues-Lima.

Conducted experiments: Xu, Mathieu, Berthelet, Duval, Bui, Busi.

Performed data analysis: Xu, Mathieu, Berthelet, Duval, Bui, Busi,

Dupret, Rodrigues-Lima.

Wrote or contributed to the writing of the manuscript: $\mathrm{Xu}$, Berthelet, Busi, Rodrigues-Lima.

\section{References}

Atanasov AG, Tam S, Röcken JM, Baker ME, and Odermatt A (2003) Inhibition of 11 beta-hydroxysteroid dehydrogenase type 2 by dithiocarbamates. Biochem Biophys Res Commun 308:257-262.

Bonifas J, Scheitza S, Clemens J, and Blömeke B (2010) Characterization of $\mathrm{N}$-acetyltransferase 1 activity in human keratinocytes and modulation by paraphenylenediamine. J Pharmacol Exp Ther 334:318-326.

Boobis AR, Ossendorp BC, Banasiak U, Hamey PY, Sebestyen I, and Moretto A (2008) Cumulative risk assessment of pesticide residues in food. Toxicol Lett 180 $137-150$.
Brady JF, Xiao F, Wang MH, Li Y, Ning SM, Gapac JM, and Yang CS (1991) Effects of disulfiram on hepatic P450IIE1, other microsomal enzymes, and hepatotoxicity in rats. Toxicol Appl Pharmacol 108:366-373

Bui LC, Manaa A, Xu X, Duval R, Busi F, Dupret JM, Rodrigues-Lima F, and Dairou $J$ (2013) Acrolein, an $\alpha, \beta$-unsaturated aldehyde, irreversibly inhibits the acetylation of aromatic amine xenobiotics by human arylamine $\mathrm{N}$-acetyltransferase 1 . Drug Metab Dispos 41:1300-1305.

Butcher NJ and Minchin RF (2012) Arylamine N-acetyltransferase 1: a novel drug target in cancer development. Pharmacol Rev 64:147-165.

Butcher NJ, Ilett KF, and Minchin RF (2000) Inactivation of human arylamine $\mathrm{N}$-acetyltransferase 1 by the hydroxylamine of p-aminobenzoic acid. Biochem Pharmacol 60:1829-1836.

Butcher NJ, Arulpragasam A, and Minchin RF (2004) Proteasomal degradation of $\mathrm{N}$-acetyltransferase 1 is prevented by acetylation of the active site cysteine: a mechanism for the slow acetylator phenotype and substrate-dependent down-regulation. J Biol Chem 279:22131-22137.

Caroldi S and De Paris P (1995) Comparative effects of two dithiocarbamates disulfiram and thiram, on adrenal catecholamine content and on plasma dopaminebeta-hydroxylase activity. Arch Toxicol 69:690-693.

Cereser C, Boget S, Parvaz P, and Revol A (2001) An evaluation of thiram toxicity on cultured human skin fibroblasts. Toxicology 162:89-101.

Copeland RA (2005) Evaluation of Enzyme Inhibitors in Drug Discovery, Wiley-Interscience, Hoboken.

Cornish-Bowden A (2001) Fundamentals of Enzyme Kinetics, Portland Press, London. Dairou J, Atmane N, Rodrigues-Lima F, and Dupret J-M (2004) Peroxynitrite irreversibly inactivates the human xenobiotic-metabolizing enzyme arylamine $\mathrm{N}$-acetyltransferase 1 (NAT1) in human breast cancer cells: a cellular and mechanistic study. $J$ Biol Chem 279:7708-7714.

Dairou J, Dupret J-M, and Rodrigues-Lima F (2005) Impairment of the activity of the xenobiotic-metabolizing enzymes arylamine N-acetyltransferases 1 and 2 (NAT1/ NAT2) by peroxynitrite in mouse skeletal muscle cells. FEBS Lett 579:4719-4723.

Dierolf D, Scheitza S, Bonifas J, and Blömeke B (2012) Cyanamide-mediated Inhibition of N-acetyltransferase 1. Toxicology 302:1-10.

Doll MA, Zang Y, Moeller T, and Hein DW (2010) Codominant expression of $\mathrm{N}$-acetylation and $\mathrm{O}$-acetylation activities catalyzed by $\mathrm{N}$-acetyltransferase 2 in human hepatocytes. J Pharmacol Exp Ther 334:540-544.

Duval R, Xu X, Bui L-C, Mathieu C, Petit E, Cariou K, Dodd RH, Dupret JM, and Rodrigues-Lima F (2016) Identification of cancer chemopreventive isothiocyanates as direct inhibitors of the arylamine $\mathrm{N}$-acetyltransferasedependent acetylation and bioactivation of aromatic amine carcinogens. Oncotarget 7:8688-8699.

Frank N, Christmann A, and Frei E (1995) Comparative studies on the pharmacokinetics of hydrophilic prolinedithiocarbamate, sarcosinedithiocarbamate and the less hydrophilic diethyldithiocarbamate. Toxicology 95:113-122.

Garbrecht MR, Krozowski ZS, Snyder JM, and Schmidt TJ (2006) Reduction of glucocorticoid receptor ligand binding by the 11-beta hydroxysteroid dehydrogenase type 2 inhibitor, Thiram. Steroids 71:895-901.

Hein DW, McQueen CA, Grant DM, Goodfellow GH, Kadlubar FF, and Weber WW (2000) Pharmacogenetics of the arylamine N-acetyltransferases: a symposium in honor of Wendell W. Weber. Drug Metab Dispos 28:1425-1432.

Hernández AF, Parrón T, Tsatsakis AM, Requena M, Alarcón R, and López-Guarnido O (2013) Toxic effects of pesticide mixtures at a molecular level: their relevance to human health. Toxicology 307:136-145.

$\mathrm{Hu}$ P, Jin L, and Baillie TA (1997) Studies on the metabolic activation of disulfiram in rat. Evidence for electrophilic S-oxygenated metabolites as inhibitors of aldehyde dehydrogenase and precursors of urinary $\mathrm{N}$-acetylcysteine conjugates. J Pharmacol Exp Ther 281:611-617.

Jin L, Davis MR, Hu P, and Baillie TA (1994) Identification of novel glutathione conjugates of disulfiram and diethyldithiocarbamate in rat bile by liquid chromatography-tandem mass spectrometry. Evidence for metabolic activation of disulfiram in vivo. Chem Res Toxicol 7:526-533.

Kawamura A, Westwood I, Wakefield L, Long H, Zhang N, Walters K, Redfield C, and Sim E (2008) Mouse N-acetyltransferase type 2, the homologue of human $\mathrm{N}$-acetyltransferase type 1. Biochem Pharmacol 75:1550-1560.

Kim D and Guengerich FP (2005) Cytochrome P450 activation of arylamines and heterocyclic amines. Annu Rev Pharmacol Toxicol 45:27-49.

Laurieri N, Dairou J, Egleton JE, Stanley LA, Russell AJ, Dupret JM, Sim E, and Rodrigues-Lima F (2014) From arylamine N-acetyltransferase to folatedependent acetyl CoA hydrolase: impact of folic acid on the activity of (HUMAN) NAT1 and its homologue (MOUSE)NAT2. PLoS One 9:e96370.

Lippmann W and Lloyd K (1969) Dopamine- -hydroxylase inhibition by dimethyldithiocarbamate and related compounds. Biochem Pharmacol 18:2507-2516.

Lipsky JJ, Shen ML, and Naylor S (2001) In vivo inhibition of aldehyde dehydrogenase by disulfiram. Chem Biol Interact 130-132:93-102.

Liu L, Wagner CR, and Hanna PE (2008) Human arylamine N-acetyltransferase 1 in vitro and intracellular inactivation by nitrosoarene metabolites of toxic and carcinogenic arylamines. Chem Res Toxicol 21:2005-2016.

Malka F, Dairou J, Ragunathan N, Dupret JM, and Rodrigues-Lima F (2009) Mechanisms and kinetics of human arylamine $\mathrm{N}$-acetyltransferase 1 inhibition by disulfiram. FEBS J 276:4900-4908.

Martins M, Rodrigues-Lima F, Dairou J, Lamouri A, Malagnac F, Silar P, and Dupret JM (2009) An acetyltransferase conferring tolerance to toxic aromatic amine chemicals: molecular and functional studies. J Biol Chem 284:18726-18733.

Mathieu C, Duval R, Xu X, Rodrigues-Lima F, and Dupret JM (2015) Effects of pesticide chemicals on the activity of metabolic enzymes: focus on thiocarbamates. Expert Opin Drug Metab Toxicol 11:81-94.

Mathieu C, Bui L-C, Petit E, Haddad I, Agbulut O, Vinh J, Dupret JM, and Rodrigues-Lima F (2017) Molecular mechanisms of allosteric inhibition of brain glycogen phosphorylase by neurotoxic dithiocarbamate chemicals. $J$ Biol Chem 292:1603-1612. 
Mushtaq A, Payton M, and Sim E (2002) The COOH terminus of arylamine $\mathrm{N}$-acetyltransferase from Salmonella typhimurium controls enzymic activity. $J$ Biol Chem 277:12175-12181.

Rasaputra KS, Liyanage R, Lay JO Jr., Slavik MF, and Rath NC (2013) Effect of thiram on avian growth plate chondrocytes in culture. J Toxicol Sci 38:93-101.

Rath NC, Rasaputra KS, Liyanage R, Huff GR, and Huff WE (2011) Dithiocarbamate Toxicity - An Appraisal, Pesticides in the Modern World - Effects of Pesticides Exposure, Intech Publisher, Rijeka.

Rodrigues-Lima F, Deloménie C, Goodfellow GH, Grant DM, and Dupret JM (2001) Homology modelling and structural analysis of human arylamine $\mathrm{N}$-acetyltransferase NAT1: evidence for the conservation of a cysteine protease catalytic domain and an active-site loop. Biochem $J$ 356:327-334.

Rodrigues-Lima F, Dairou J, Diaz CL, Rubio MC, Sim E, Spaink HP, and Dupret JM (2006) Cloning, functional expression and characterization of mesorhizobium loti arylamine $\mathrm{N}$-acetyltransferases: rhizobial symbiosis supplies leguminous plants with the xenobiotic N-acetylation pathway. Mol Microbiol 60:505-512.

Rodrigues-Lima F, Dairou J, and Dupret J-M (2008) Effect of environmental substances on the activity of arylamine N-acetyltransferases. Curr Drug Metab 9: 505-509.

Russell AJ, Westwood IM, Crawford MH, Robinson J, Kawamura A, Redfield C, Laurieri N, Lowe ED, Davies SG, and Sim E (2009) Selective small molecule inhibitors of the potential breast cancer marker, human arylamine $\mathrm{N}$-acetyltransferase 1 , and its murine homologue, mouse arylamine N-acetyltransferase 2. Bioorg Med Chem 17:905-918.

Scheitza S, Bonifas J, and Blömeke B (2012) Variable NAT1 enzyme activity in longterm cultured human HaCaT keratinocytes. J Toxicol Environ Health A $\mathbf{7 5}$ 471-477.

Sim E, Fakis G, Laurieri N, and Boukouvala S (2012) Arylamine $\mathrm{N}$-acetyltransferases-from drug metabolism and pharmacogenetics to identification of novel targets for pharmacological intervention. Adv Pharmacol 63 169-205.

Sinclair JC, Delgoda R, Noble ME, Jarmin S, Goh NK, and Sim E (1998) Purification, characterization, and crystallization of an N-hydroxyarylamine O-acetyltransferase from Salmonella typhimurium. Protein Expr Purif 12: 371-380.

Staub RE, Quistad GB, and Casida JE (1998) Mechanism for benomyl action as a mitochondrial aldehyde dehydrogenase inhibitor in mice. Chem Res Toxicol 11 $535-543$.
Stepp MW, Mamaliga G, Doll MA, States JC, and Hein DW (2015) Folate-dependent hydrolysis of acetyl-coenzyme A by recombinant human and rodent arylamine N-acetyltransferases. Biochem Biophys Rep 3:45-50.

Tixier C, Sancelme M, Aït-Aïssa S, Widehem P, Bonnemoy F, Cuer A, Truffaut N, and Veschambre H (2002) Biotransformation of phenylurea herbicides by a soil bacterial strain, Arthrobacter sp. N2: structure, ecotoxicity and fate of diuron metabolite with soil fungi. Chemosphere 46:519-526.

Tweedy BG, Loeppky C, and Ross JA (1970) Metobromuron: acetylation of the aniline moiety as a detoxification mechanism. Science 168:482-483.

van Boxtel AL, Pieterse B, Cenijn P, Kamstra JH, Brouwer A, van Wieringen W, de Boer J, and Legler J (2010) Dithiocarbamates induce craniofacial abnormalities and downregulate sox9a during zebrafish development. Toxicol Sci 117:209-217.

Viquez OM, Caito SW, McDonald WH, Friedman DB, and Valentine WM (2012) Electrophilic adduction of ubiquitin activating enzyme E1 by N,Ndiethyldithiocarbamate inhibits ubiquitin activation and is accompanied by striatal injury in the rat. Chem Res Toxicol 25:2310-2321.

Wang H, Liu L, Hanna PE, and Wagner CR (2005) Catalytic mechanism of hamster arylamine N-acetyltransferase 2. Biochemistry 44:11295-11306.

Witham KL, Butcher NJ, Sugamori KS, Brenneman D, Grant DM, and Minchin RF (2013) 5-methyl-tetrahydrofolate and the S-adenosylmethionine cycle in C57BL/6J mouse tissues: gender differences and effects of arylamine N-acetyltransferase-1 deletion. PLoS One 8:e77923.

Witham KL, Minchin RF, and Butcher NJ (2017) Role for human arylamine $\mathrm{N}$-acetyltransferase 1 in the methionine salvage pathway. Biochem Pharmacol 125:93-100.

Yuan Y, Zhang P, Schäffer A, and Schmidt B (2017) 3,4-Dichloroaniline revisited: a study on the fate of the priority pollutant in a sediment-water system derived from a rice growing region in Italy. Sci Total Environ 574:1012-1020.

Zimmerman LJ, Valentine HL, and Valentine WM (2004) Characterization of S-(N,N Dialkylaminocarbonyl)cysteine adducts and enzyme inhibition produced by thiocarbamate herbicides in the rat. Chem Res Toxicol 17:258-267.

Address correspondence to: Fernando Rodrigues Lima, Université Paris Diderot, Sorbonne Paris Cité, Unité BFA, CNRS UMR 8251, 75013, Paris, France. E-mail: fernando.rodrigues-lima@univ-paris-diderot.fr 